\title{
Species composition and pedological characteristics of biological soil crusts in a high alpine ecosystem, Hohe Tauern, Austria
}

\author{
Thomas Peer, Roman Türk, Johann Peter Gruber \& Angelika Tschaikner
}

Keywords: Biological soil crusts, species composition, soil physicochemical characteristics, Hohe Tauern National Park, Austria

Abstract

Within the Hohe Tauern National Park (Austria), we studied biological soil crusts (BSCs) in the surroundings of the Hochtor and the Großglockner High Alpine Road (2500-2600 m). Biological soil crusts (BSCs) consist of cyanobacteria, algae, lichens, and bryophytes, which alter soil factors, including water availability, nutrient content, and susceptibility to erosion.

We detected approximately 45 taxa of Cyanoprokaryota and eukaryotic algae, 51 taxa of lichens, and 38 taxa of bryophytes at our study sites, of these the darkcoloured lichen Toniniopsis obscura is dominant. Bryophytes and vascular plants are of minor importance. Compared to uncrusted sites, crust sites exhibit significantly higher contents of organic matter, total nitrogen, and plant-available nutrients. Water storage capacity and aggregate stability are also higher in the crusted soils. Susceptibility to erosion is one fourth lower in crusted soils than in uncrusted soils. Preliminary results also suggest that BSCs are captors for heavy metals as they accumulate higher amounts of atmogenic heavy metals than bare soils.
Profile

Protected area

Hohe Tauern National Park

Mountain range

Alps

Country

Austria

\section{Introduction}

Biological soil crusts (BSCs, also referred to as cryptogamic, cryptobiotic, microbiotic, or microphytic crusts) are a complex mosaic of cyanobacteria, algae, microfungi, lichens, mosses and liverworts growing on and within the uppermost layers of the soil (Büdel 2002; Büdel 2003; Büdel 2005; Belnap \& Lange 2005). BSCs are mainly described for semi-arid and arid ecosystems worldwide (e. g. West 1990; Johansen 1993; Eldridge \& Greene 1994; Belnap, Büdel \& Lange 2003; Tirkey \& Adhikary 2005). In these areas, they fulfil a number of important ecological functions, including soil stabilization, atmospheric nitrogen fixation $\left(\mathrm{N}_{2}\right)$, nutrient storage and vascular plant establishment (Shields \& Durrell 1964; Griffiths 1965; Campell et al. 1989; Danin et al. 1989; Belnap \& Gardner 1993; Moore 1998; Belnap et al. 2001; Aranibar et al. 2003; Belnap 2003a; Belnap et al. 2003; Lange 2003; Housman et al. 2006).

The filamentous cyanobacteria form entangled structures that tighten the soil surface and protect it from erosion. Mucilage produced by the cyanobacteria serves as a binding agent, and photosynthesis products enrich the soil with organic matter which improves its structure and biological activity (Lange et al. 1994; Lange et al. 1998). Because many cyanobacteria and cyanobacterial lichens are capable of fixing nitrogen, the soil is enriched with nitrogen, improving growth conditions for plants (Davey \& Marchant 1983; Smith et al. 1990; Belnap \& Gardner 1993; Belnap \& Harper 1995; Harper \& Belnap 2001; Belnap 2002; Belnap 2003b; Belnap et al. 2003; Russow et al. 2005).

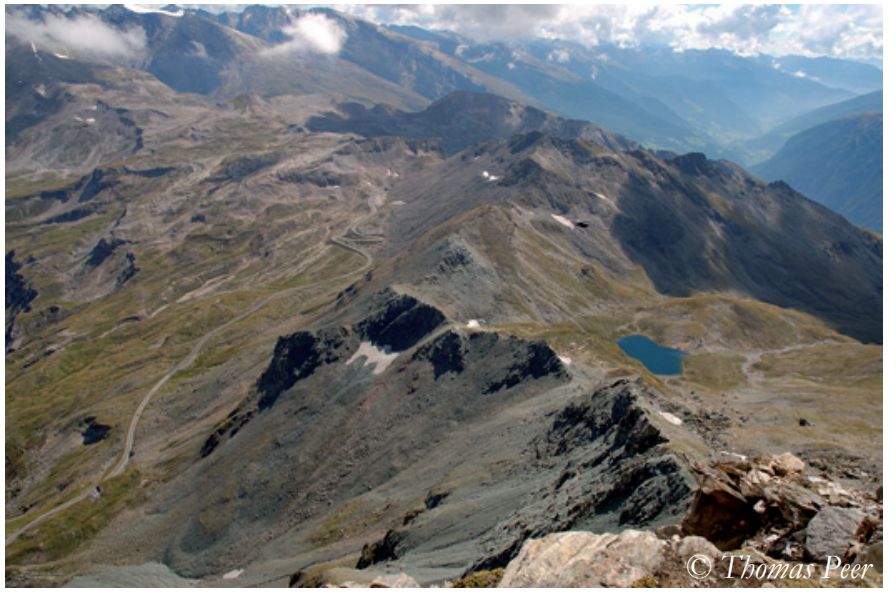

Hochtor, Großglockner High Alpine Road, Hohe Tauern National Park

In contrast to the numerous studies from arid lands, knowledge about BSCs in alpine ecosystems is patchy. With the exception of Pérez (1997) who investigated the microbiotic crusts in the high equatorial Andes, and Gold et al. (2001) who analysed the functional influences of cryptobiotic crusts in an alpine tundra basin of the Olympic Mountains (Washington, USA), only Türk \& Gärtner (2003) give an overview of the organism diversity in BSCs of the Alps and Huber K. et al. (2007) deal with alpine soil crusts, carrying out their studies in high alpine sites of the Großglockner area (Hohe Tauern, Austria). In continuation of this investigation, we extended our research program in the last two years, including new sites, with particular emphasis on the following topics: 1) species composition, 2) comparison of crust properties with those of 
uncrusted sites, 3) successional stages of BSCs, and 4) possible consequences of external disturbances for biological crusts.

\section{Material and methods}

Study sites

The study was conducted at sites west and east of the Hochtor, close to the Großglockner High Alpine Road, located at $47^{\circ} 05^{\prime} 00^{\prime} \mathrm{N}$ and $12^{\circ} 50^{\prime} 34^{\prime \prime} \mathrm{E}$ (Figure 1). The elevation of the study sites ranges from 2500 to $2600 \mathrm{~m}$, the annual precipitation averages $2000 \mathrm{~mm}$, and the mean air temperature ranges from $-10^{\circ} \mathrm{C}$ to $-8^{\circ} \mathrm{C}$ in January and from $2^{\circ} \mathrm{C}$ to $4^{\circ} \mathrm{C}$ in July. $70-80 \%$ of the precipitation falls as snow and snow cover lasts 270 to 300 days (Auer et al. 2002). Due to strong wind effects, fine-earth translocation over long distance is typical (Gruber 1980). Five transects of 5 to $20 \mathrm{~m}$ length were set, both on siliceous sites within the Brennkogel formation (B1 and B2) and on calcareous sites within the Seidlwinkl Triassic formation (Plattenkar, Schareck). Each transect includes a transition zone from crusted to non-crusted sites.

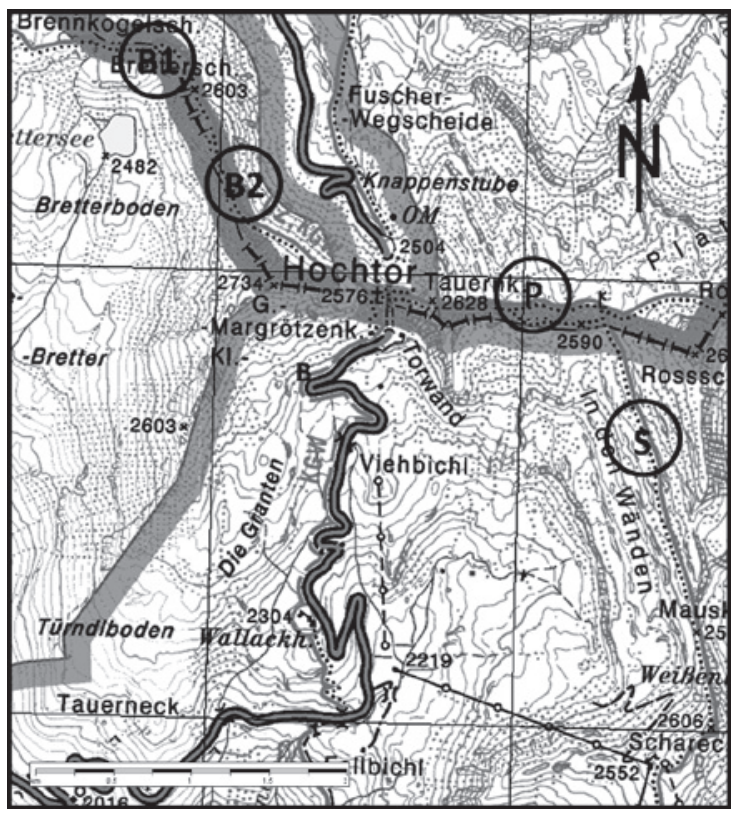

Figure 1 - Location of the sites from where the samples were taken (B1, B2 = Brennkogel, $P=$ Plattenkar, $S=$ Schareck. Source: Austrian map 1:50.000, (C) BEV 2010, reproduction granted by the BEV - Bundesamt für Eich-und Vermessungswesen in Wien, T2010/64080

Data collection and analysis

We rated composition and abundance of lichens, bryophytes and vascular plants along each transect using a frequency frame of $10 \mathrm{~cm} \times 20 \mathrm{~cm}$. Soil types were described on spade-dug pits and classified according to the World Reference Base for Soil Resources (WRB 2006). We collected soil samples at $1 \mathrm{~m}$ to $5 \mathrm{~m}$ intervals, both from upper soil layer $(0-2 \mathrm{~cm})$ where soil is mostly affected by biological crusts and from uncrusted soil sites, covering a depth range of up to $10 \mathrm{~cm}$. In addition, samples were also taken beneath crust layer to evaluate the vertical distribution of heavy metals. For this investigation, we selected an area of about 1 ha, including different distances from the Großglockner High Alpine Road, and different slope directions. At each sampling point, five replicate soil samples were taken and mixed. We used metal cylinders $(\varnothing 5 \mathrm{~cm}$, length $1 \mathrm{~cm}$ ) to obtain the samples for microbiological analyses at the sites of the soil sample plots. Cultivation and determination of Cyanoprokaryota and eukaryotic soil algae was carried out at the Botanical Institute of the University of Innsbruck (Bischof \& Bold 1963; Gärtner 1996). The samples for physicochemical analyses were air-dried and sieved $(<2 \mathrm{~mm})$ and the samples for heavy metal analyses were ovendried $\left(105^{\circ} \mathrm{C}\right)$ and ground in a ball mill. In our study, we applied ÖNORM and ISO standards on soils (see Blum et al. 1996):

soil $\mathrm{pH}$ : electrometric in $0,01 \mathrm{M} \mathrm{CaCl}_{2}$ dilution; particle-size distribution (soil texture) by the pipette method and sieving;

organic matter content by dry combustion of carbon "total" nitrogen by the Kjeldahl method;

plant-available phosphate and potassium by the calcium-acetate-lactate (CAL) method;

heavy metals: acid digestion $\left(\mathrm{HNO}_{3}: \mathrm{HCl}=3: 1\right)$ using the microwave technique; determination of $\mathrm{Cu}$, $\mathrm{Zn}$ and $\mathrm{Pb}$ by flame AAS, determination of $\mathrm{Cd}$ by graphite furnace AAS;

water storage capacity: gravimetric after soil saturation with water and drying at $105^{\circ} \mathrm{C}$;

aggregate stability: water drop experiment according to McCalla (1944), modified by Griffiths (1965). Water drops of a defined size and with a defined frequency were dropped upon dried soil particles of $1 \mathrm{~mm}$ size from a defined height. The proportion of soil particles washed through a $1 \mathrm{~mm}$ sieve was rated by a given number of drops;

soil erodibility was estimated according to the empirical soil loss model (modified) by Wischmeier \& Smith (1978). The erodibility factor $(K)$ is based on different laboratory analyses including particle size analysis and organic matter content as well as field assessment of soil structure and permeability.

Taxon identification and nomenclature followed Ettl \& Gärtner (1995) for Cyanoprokaryota and eukaryotic algae, Frey at al. (1995) for mosses and liverworts and Poelt (1969), Poelt \& Vězda (1977; 1981), Wirth (1995) and Hafellner \& Türk (2001) for lichens. Vascular plant nomenclature followed that in Fischer et al. (2008). The Mann-Whitney U-test was used to compare soil properties in crusted and uncrusted soils using SPSS programs for Windows, version 16. 


\section{Results and discussion}

Species composition

Approximately 45 taxa of Cyanoprokaryota and eukaryotic algae were recorded in samples within transects and adjacent sites (Table 1). Among them, green algae (Chlorophyta) are the biggest group with 35 taxa; yellow-green algae (Xanthophyta, Eustig- matophyta) exhibit 7 taxa, and blue-green algae (Cyanoprokaryota) are present with 3 taxa. Within the Cyanoprokaryota, the heterocystous genera Nostoc and Anabaena are common. They are capable of nitrogen fixation and they also produce extracellular polysaccharides, which enables them to aggregate soil particles. The yellow-green algae Botrydiopsis (constricta) and Eustigmatos (vischeri) have coccoid forms whereas

Table 1 - Species composition in soil crusts from different sites of the Großglockner area (taxa arranged alphabetically)

\begin{tabular}{|c|c|c|}
\hline Cyanoprokaryota and eukaryotic algae & Lichens & Bryophytes \\
\hline Anabaena spec. & Agonimia tristicula & Anthelia juratzkana \\
\hline Botrydiopsis spec. (cf. constricta) & Allocetraria madrepoiformis & Blepharostoma trichophyllum \\
\hline Botrydiopsis spec. & Arthrorhaphis alpina & Blindia cespiticia \\
\hline Bracteacoccus engadinensis & Baeomyces placophyllus & Brachythecium glaciale \\
\hline Bumilleriopsis spec. & Buellia elegans & Brachythecium velutinum \\
\hline Clamidocapsa lobata & Buellia papillata & Bryum argenteum \\
\hline Chlorella ellipsoidea & Caloplaca bryochrysion & Bryum imbricatum \\
\hline Chlorella vulgaris (var. vulgaris) & Caloplaca cerina var. muscorum & Bryum pallescens \\
\hline Clorella vulgaris (var. autotrophica) & Caloplaca stillicidiorum & Bryum spec. \\
\hline Chlorella vulgaris (var. viridis) & Catapyrenium aureum & Campylium chrysophyllum \\
\hline Chlorococcum spec. & Cetraria islandica & Campylium spec. \\
\hline Chlorotetraedron polymorphum & Cetraria muricata & Cirriphyllum cirrhosum \\
\hline Choricystis (minor) & Cladonia macroceras & Conocephalum conicum \\
\hline Clamidocapsa lobata & Cladonia pyxidata & Didymodon latifolium \\
\hline Choricystis (minor) & Cladonia symphycarpa & Distichium capillaceum \\
\hline Chlorosarcinopsis spec. & Collema tenax & Distichium inclinatum \\
\hline Chlorotetraedron polymorphum & Dacampia hookeri & Ditrichum heteromallum \\
\hline Coccomyxa confluens agg. & Dibaeis baeomyces & Ditrichum spec. \\
\hline Coelastrella (aeroterrestrica) & Fulgensia bracteata subspec. deformis & Drepanocladus uncinatus \\
\hline Coelastrella spec. & Gyalecta foveolaris & Encalypta cf. alpina \\
\hline Cylindrocystis (brebissonii) & Lecanora epibryon & Hypnum bambergeri \\
\hline Eustigmatos (vischeri) & Lecanora hagenii var. fallax & Hypnum revolutum \\
\hline Geminella spec. & Lecidella wulfenii & Leiocholea spec. \\
\hline Gloeocystis papuana & Megaspora verrucosa & Lophozia spec. \\
\hline Klebsormidium (dissectum) & Micarea assimilata & Lophozia sudetica \\
\hline Klebsormidium (flaccidum) & Myxobilimbia lobulata & Meesia uliginosa \\
\hline Leptosira (errumpens) & Myxobilimbia microcarpa & Pohlia spec. \\
\hline Lobosphaeropsis spec. & Parmelia saxatilis & Polytrichum alpinum \\
\hline Monodus cf. coccomyxa & Peltigera rufescens & Polytrichum norvegicum \\
\hline Monoraphidum spec. & Pertusaria glomerata. & Pottiaceae \\
\hline Muriella terrestris & Phaerorrhiza nimbosa & Racomitrium spec. \\
\hline Nostoc (punctiforme) & Physconia muscigena & Sanionia uncinata \\
\hline Nostoc sporangieforme & Placidium spec. & Scapania cuspiduligera \\
\hline Phormidium spec. & Polyblastia sendtneri & Scapania helvetica \\
\hline Podohedra spec. (or Keratococcus spec.) & Polyblastia tatrana & Tortula norvegica \\
\hline Pseudoanabaena spec. & Protoblastenia terricola & Tortella tortuosa \\
\hline Pseudoschzomeris spec. & Protopannaria pezizoides & Tortula ruralis \\
\hline Radiosphaera spec. & Psora decipiens & Tayloria froelichiana \\
\hline Scotiellopsis oocystiformis & Rinodina roscida & \\
\hline Stichococcus bacillaris & Squamaria gypsacea & \\
\hline Stichococcus minutus & Solorina bispora & \\
\hline Stichococcus spec. & Solorina octospora & \\
\hline Xanthonema (debile) & Solorina saccata & \\
\hline Xanthonema (hormidioides) & Solorina spec. & \\
\hline \multirow[t]{5}{*}{ Xanthonema (montanum) } & Thelopsis melathelia & \\
\hline & Toninia diffracta & \\
\hline & Toniniopsis obscura & \\
\hline & Variecellaria rhodocarpa & \\
\hline & Vulpicida tubulosus & \\
\hline
\end{tabular}


the Xanthonema species are filamentous. Filamentous forms are suitable for binding mineral particles together and thus facilitate soil aggregation.

Within green algae, the species Cylindrocystis (brebissonii) and different members of the Chlorella species are common. The species Coelastrella aeroterrestrica is characterized by a fine network of cell wall ribs visible only in the scanning electron microscopy (SEM). Stiffeners on the cell wall can be interpreted as an adaption to the severe alpine climate (Tschaikner et al. 2008). Most of the observed taxa are distributed across the world but with some concentration in cold (arctic) regions.

Among lichens, gelatinous, crustose and small foliose species take up most of the crust surface. Species are closely attached to the substrate, with some of them stabilizing the upper-most soil layer with rhizohyphae and rhizinae. We encountered approximately 51 taxa, including species such as Buellia elegans, Catapyrenium cinereum, Cladonia macroceras, Cladonia symphycarpa, Fulgensia bracteata subsp. deformis, Myxobilimbia lobulata, Parmelia saxatilis, Psora decipiens, Solorina bispora and Toniniopsis obscura. Since the photobiont of Collema tenax is the cyanobacterium genus Nostoc, the lichen is capable of nitrogen fixation.

Compared to algae and lichens, bryophytes (including mosses and liverworts) contribute little to biomass and cover degree within alpine soil crusts. This fact might be closely linked to the competition pressure of lichens (primarily through the species Toniniopsis obscura), which are better adapted to short dry periods than bryophytes. However, bryophytes can establish only on sites where the crust layer is cracked, but they are often poorly developed (small scrubby forms) and thus difficult to identify. Due to the harsh climate, the above-ground biomass of bryophytes is low, but the subterranean moss protonemata and rhizoids, which are interspersed throughout the soil crust matrix, are of major importance and are likely to contribute to soil stability.

We recorded approximately 38 taxa, among them 7 liverworts, in the study area. Most of them are ubiquitous and exhibit a wide altitudinal range (colline to alpine). Common members within BSCs are the Bryum species, Distichum capillaceum and Meesia uliginosa. The ecotype Meesia uliginosa var. was recorded in habitats of low humus content and up to $3000 \mathrm{~m}$ elevation (Grims 1999). Among liverworts, the species Lophozia sudetica prefers stony and peaty substrates of acidic and wet habitats.

In contrast to the lichen-dominated soil crusts occurring on fine gravelly slopes, patches with long snow cover are rich in bryophytes such as Anthelia juratzkana and Polytrichum sexangularis. The species Anthelia juratzkana is associated with the cyanobacterium Gloecapsa montana. Its gelatinous sheaths are responsible for the waxy, whitish appearance. The liverwort is well adapted to low temperatures and wet habitat conditions and may survive even if the snow cover lasts 8 to 10 months (Lösch et al. 1983; Riedl 1977).
Vascular plants are not a direct part of cryptogamic crusts. They mostly start growing from cracks and gaps in crusts and spread across the crust surface with their runners forming a wide net over the years. In the study area, only few species colonize bare scree slopes, mostly they are cushion plants like Saxifraga oppostifolia (also develops runners), Silene acaulis s. l. and Minuartia sedoides; also present are the creeper Salix serpillifolia and the tuft grass Oreochloa disticha. These plants are well adapted to permanent slope movement, wind force and drought. On sites where the snow lies longer, phanerogames are normally rare with the exception of Salix herbacea, Gentianella nana, Ranunculus alpestris, Sagina saginoides, Saxifraga androsacea (relatively abundant) and Soldanella pusilla. The alpine sward associations such as the Caricetum curvulae (or Curvuletum) on acidic sites, the Seslerio-Semperviretum on calcareous sites and the Elynetum on wind edges, need deeper and better consolidated soils. In these sward communities, BSCs are limited to gaps between the plants.

\section{Soil characteristics and successional stages}

Soil types on cellular dolomite, dolomite, and chalk marble occurring east of the Hochtor include pale Skeletic Regosols on gravelly scree slopes, and Rendzic Regosols on fine weathered carbonatic (gypsiferous) material. The Skeletic Regosols consist of a thin layer of Cyanoprokaryota that live on or just below the soil surface. Cyanoprokaryota and eukaryotic algae belong to the first colonizers and together with aeolian deposits, including mineral and organic components (see Gruber 1980; Küfmann 2009), they contribute to a first pedogenesis. The Rendzic Regosol has a $1 \mathrm{~cm}$ to $3 \mathrm{~cm}$ thick A-horizon and is covered with a $0.2 \mathrm{~cm}$ to $1 \mathrm{~cm}$ thick crust layer. The crust surface sometimes has a polygonal structure and an uplifted (rolling) surface as a result of frost. Crust biomass and water absorbance capacity are high in this crust type because algae, bryophytes and lichens absorb a lot of water (Brotherson \& Rushford 1983; Eldridge 2003; Huber $\mathrm{K}$. et al. 2007). Once the soil surface is covered by lichens and bryophytes, the underlying soil is protected from raindrop impact and resists detachment of particles during surface flow events (Belnap \& Lange 2005; Lazaro et al. 2008). Lichens and bryophytes also have anchoring structures (rhizinae, and rhizohyphae) that penetrate down into the soil as deep as $15 \mathrm{~mm}$.

On mica schists, green schists, phyllites and gneiss occurring west of the Hochtor, acid Cambisols with depths of $15 \mathrm{~cm}$ to $25 \mathrm{~cm}$ are common. Because of permanent slope movement (gelifluctuation), the whole solum is interspersed with stones of different sizes. When soils are young and relatively unweathered, only a thin layer of Cyanoprokaryota occurs whereas on better consolidated soils a thicker, lichen-dominated rolling crust is typical. The $\mathrm{pH}$ value ranges from 6.4 to 7.7 on limestone sites and from 4.5 to 6.2 on siliceous sites. The soil texture corresponds to loamy 
Table 2 - Average values of soil properties in crusts and adjacent bare soils in the limestone area. All values indicate means and standard deviation

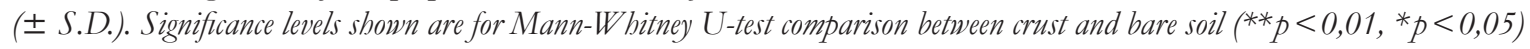

\begin{tabular}{|c|c|c|c|c|c|c|c|c|c|}
\hline & $\underset{\mathrm{CaCl}_{2}}{\mathrm{pH}}$ & $\underset{\%}{\text { clay }+ \text { fine silt }}$ & $\begin{array}{c}\text { humus content } \\
\%\end{array}$ & $\begin{array}{c}\text { Kieldahl-N } \\
\%\end{array}$ & $\begin{array}{c}\mathrm{K} \\
\mathrm{mg} / 100 \mathrm{~g}\end{array}$ & $\begin{array}{c}P \\
\mathrm{mg} / 100 \mathrm{~g}\end{array}$ & $\begin{array}{l}\text { water storage } \\
\text { capacity } \\
\mathrm{ml} / \mathrm{cm}^{3}\end{array}$ & $\begin{array}{c}\text { aggregate } \\
\text { stability } \\
\%\end{array}$ & $\begin{array}{c}\text { soil } \\
\text { erodibility } \\
\text { K-factor }\end{array}$ \\
\hline $\begin{array}{l}\text { crust } \\
(n=15)\end{array}$ & $\begin{array}{c}7,21 \\
\pm 0,37\end{array}$ & $\begin{array}{l}10,85^{*} \\
\pm 1,76\end{array}$ & $\begin{array}{c}13,32^{* *} \\
\pm 4,73\end{array}$ & $\begin{array}{l}0,17^{* *} \\
\pm 0,12\end{array}$ & $\begin{array}{c}22,04^{* *} \\
\pm 2,69\end{array}$ & $\begin{array}{l}3,18^{* *} \\
\pm 0,96\end{array}$ & $\begin{array}{l}0,567 \\
\pm 0,18\end{array}$ & $\begin{array}{l}85,28^{* *} \\
\pm 14,58\end{array}$ & $\begin{array}{l}1,48^{*} \\
\pm 0,17\end{array}$ \\
\hline $\begin{array}{l}\text { bare soil } \\
(n=14)\end{array}$ & $\begin{array}{c}7,50 \\
\pm 0,40\end{array}$ & $\begin{array}{c}8,35 \\
\pm 1,67\end{array}$ & $\begin{array}{l}1,22 \\
\pm 0,71\end{array}$ & $\begin{array}{c}0,09 \\
\pm 0,11\end{array}$ & $\begin{array}{c}4,67 \\
\pm 2,84\end{array}$ & $\begin{array}{c}0,49 \\
\pm 0,27\end{array}$ & $\begin{array}{l}0,452 \\
\pm 0,14\end{array}$ & $\begin{array}{c}36,16 \\
\pm 22,87\end{array}$ & $\begin{array}{r}1,95 \\
\pm 0,34\end{array}$ \\
\hline
\end{tabular}

Table 3 - Averages values of heavy metals in crust and underlying soil (preliminary results). All values (in $\mathrm{mg} / \mathrm{kg}$ DM) indicate means and standard deviation ( \pm S.D.). Significance levels shown are for Mann-Whitney U-test comparison between crust and underlying soil (**p $<0,01)$

\begin{tabular}{|l|c|c|c|c|c|}
\hline & $\mathbf{C d}$ & $\mathbf{C u}$ & $\mathbf{N i}$ & $\mathbf{P b}$ & $\mathbf{Z n}$ \\
\hline crust $(\mathrm{n}=21)$ & $0,41 \pm 0,10^{* *}$ & $11,49 \pm 5,88$ & $22,38 \pm 2,82$ & $107,77 \pm 53,85^{* *}$ & $62,56 \pm 21,45^{* *}$ \\
\hline underlying soil $(\mathrm{n}=23)$ & $0,13 \pm 0,08$ & $15,07 \pm 10,50$ & $25,38 \pm 3,14$ & $45,57 \pm 20,54$ & $36,24 \pm 14,2$ \\
\hline
\end{tabular}

sand without significant differences between sites. Humus content (top soil) is between $9.9 \%$ and $18.7 \%$ in acid soils, and between $7.9 \%$ and $21.3 \%$ in calcareous soils. This high amount of humus content is typical for Umbric Leptosols or "Alpine Humus Soils" (see Posch 1977). In contrast, total nitrogen content is rather low in the topsoil, and ranges from $0.12 \%$ to $0.26 \%$ in calcareous soils, and from $0.13 \%$ to $0.33 \%$ in siliceous soils. This could be caused by low annual temperature which hampers cyanobacterial activity and N-fixation (Horne 1972; Davey \& Marchant 1983; Haselwandter 1983; Gold et al. 2001; Huber E. et al. 2007). Denitrification and nitrate eluviations are also potential losses (Belnap 2002; Belnap 2003b). On the other hand, nitrogenous precipitation, melt water and also mineral dust are often additional sources of soluble $\mathrm{N}$ compounds in alpine soils. According to Psenner \& Nickus (1986) and Graber et al. (1996), the impact of atmogenic $\mathrm{N}$ in the Central Alps is between 0.1 and $1.4 \mathrm{~g} \mathrm{~N} / \mathrm{m}^{2}$ per year, maybe supplemented by anthropogenic ones. In this respect, we have to calculate the traffic related $\mathrm{NO}_{\mathrm{x}}$ emissions of the Großglockner High Alpine Road, with 350000 vehicles per season one of the most frequented mountain roads of the Alps. Unfortunately, no data is available on air-borne nitrogen pollutants for the Hochtor site so far.

In the limestone area, the crust layer exhibits higher contents of clay and fine silt, organic matter and total nitrogen. Water storage capacity and aggregate stability are also higher in the crusted soils. However, susceptibility to erosion in crusted soils is one fourth lower than in uncrusted soils (Table 2). Total nitrogen level in crusted soils averages about twice that of uncrusted soils. Plant availability of phosphate is 6 times higher and that of potassium is 5 times higher than in uncrusted soils. The differences between crusts and non-crusty surfaces are significant, with the exception of the $\mathrm{pH}$ and the water storage capacity.

According to our preliminary studies, BSCs also act as captors for atmogenic heavy metals. This is especially true for lead: its highest value reaches $239 \mathrm{mg} / \mathrm{kg}$ of dry matter. While lead, cadmium and zinc have higher concentrations in crusts, those of copper and nickel are higher in the subsoil (Table 3). The extra high amount of lead may be due to long distance input or is traffic-related and can be considered as residual waste from the time when petrol was leaded. In any case, the slope direction rather than the distance from the road seems to be crucial for the distribution of lead. In accordance with the main wind direction, the NW-facing slopes are more contaminated with lead than the slopes of other directions. Further research on this topic is already in progress.

\section{Conclusions}

The research on alpine soil crusts has illustrated the importance of BSCs for soil stabilization, nitrogen fixation, nutrient availability and vascular plant establishment even in alpine environments. Airborne silt and clay particles as well as humus particles can be trapped by sticky cyanobacterial sheaths, and by surface roughness created by biological crusts. This results in a higher amount of silt, clay and humus on the soil surface, improving fertility and water absorbency of the soil. Rolling crusts also affect vascular plants as they retain seeds, which mainly germinate in crust interspaces. According to our observations, crusts do not inhibit shoot spread and root penetration after seedling germination. It is expected that an increase in biomass and cover of all these crust organisms yields valuable benefits for alpine ecosystems. In particular, biological soil crusts should be considered a key factor in soil nitrogen turnover, able to support the nitrogen needs of bryophytes and vascular plants, but the regulating mechanisms have not really been understood so far (see Dickson 2000; Breen \& Lévesque 2008). Therefore, our object for the future will be to clear up open questions about nitrogen turnover and to corroborate hypothetical approaches by our own investigations. 
Management implications

However, BSCs are highly vulnerable to disturbances. Trampling by hikers and livestock (sheep and goats) may destroy the quite fragile crust layer. Once the connections between crust aggregates have been broken, the crust becomes liable to wind and water erosion that bares the subsoil. Once the soil is removed by erosion, the ecosystem has lost its basis for plant growth (cf. Brotherson et al. 1983; Beymer \& Klopatek 1992; Belnap 1995; Belnap 1996; Belnap \& Gillete 1996; Eldridge 1998; Evans \& Belnap 1999; Eldridge \& Leys 2003). Even at our sites, near paths and on wind-exposed crests, we repeatedly noticed damages on the crust layer caused by mechanical forces and/or climatic constraints. How long recovery of crust cover and species richness may take and how the succession of organisms proceeds would be another research topic for the future. The Hohe Tauern National Park with its high protection status is in an excellent position to promote such activities to gain insight on natural processes through long-term observation. Furthermore, based on our preliminary studies, the management of the Hohe Tauern National Park should make visitors aware of the ecological significance of BSCs as well as their vulnerability to outsides disturbances and what could happen once BSCs have been destroyed.

\section{Acknowledgments}

We thank Dr. Wolfhard Ruetz for his useful comments and help with the English version. We gratefully acknowledge financial support from the Glockner ÖkoFonds.

\section{References}

Aranibar, J.N., I.C. Anderson, S. Ringrose \& S.A. Macko 2003. Importance of nitrogen fixation in soil crusts of southern African arid ecosystems: acetylene reduction and stable isotope studies. Journal of Arid Environments 54: 345-358.

Auer, I., R. Böhm, M. Leymüller \& W. Schöner 2002. Das Klima des Sonnblicks - Klimaatlas und Klimatographie der GAW Station Sonnblick einschließlich der umgebenden Gebirgsregion. Österreichische Beträge zur Meteorologie und Geophysike 28: 1-408. Zentralanstalt für Meteorologie und Geodynamik. Wien.

Belnap, J. 1995. Surface disturbances: their role in accelerating desertification. Environmental Monitoring and Assessment 37: 38-57.

Belnap, J. 1996. Soil surface disturbance in cold deserts: effects on nitrogenase activity in cyanobacteriallichen soil crusts. Biology and Fertility of Soils 23: 263-267.
Belnap, J. 2002. Nitrogen fixation in biological soil crusts from southeast Utha, USA. Biology and Fertility of Soils 35: 128-135.

Belnap, J. 2003a. Comparative structure of physical and biological soil crusts. In: Belnap, J. \& O.L. Lange (eds.), Biological soil crusts: structure, function, and management. Ecological Studies 150: 177-191.

Belnap, J. 2003b. Factors influencing nitrogen fixation and nitrogen release in biological soil crusts. In: Belnap, J. \& O.L. Lange (eds.), Biological soil crusts: structure, function, and management. Ecological Studies 150: 241-261.

Belnap, J., B. Büdel \& O.L. Lange 2003. Biological soil crusts: characteristics and distribution. In: Belnap, J. \& O.L. Lange (eds.), Biological soil crusts: structure, function, and management. Ecological Studies 150: 3-31.

Belnap, J., D. Eldridge, J.H. Kaltenecker, S. Leonard, R. Rosentreter \& J. Williams 2001. Biological soil crusts: ecology and management. Technical reference 1730-2. U.S. Department of the Interior. Available at: www. soilcrust. org/crust.pdf (date: 03/10/06).

Belnap, J. \& J.S. Gardner 1993. Soil microstructure of the Colorado Plateau: the role of the cyanobacterium Microcoleus vaginatus. Great Basin Naturalist 53: 40-47.

Belnap, J. \& D.A. Gillete 1998. Vulnerability of desert biological soil crusts to wind erosion: the influence of crust development, soil texture, and disturbance. Journal of Arid Environments 39: 133-142.

Belnap, J. \& K.T. Harper 1995. Influence of cryptobiotic soil crusts on elemental content of tissue of two desert seed plants. Arid Land Research and Management 9: 107-115.

Belnap, J. \& O.L. Lange 2005. Lichens and microfungi in biological soil crusts: community structure, physiology, and ecological functions. In: Dighton, J., J.F. White \& P. Oudemans (eds.), The fungal community. Its organization and role in the ecosystem 23: 397-712.

Belnap, J., R. Prasse \& K.T. Harper 2003. Influence of biological soil crusts on soil environments and Vascular Plants. In: Belnap, J. \& O.L. Lange (eds.), Biological soil crusts: structure, function, and management. Ecological Studies 150: 281-300.

Beymer, R.J. \& J.M. Klopatek 1992. Effects of grazing on cryptogamic crusts in pinyon-juniper woodlands in Grand Canyon National Park. American Midland Naturalist 127: 139-148.

Bischoff, H. \& H.C. Bold 1963. Phycological studies IV. Some soil algae from enchanted rock and related algal species. University of Texas Publications 6318: 1-95

Blum, W.E.H., H. Spiegel \& W.W. Wenzel 1996. Bodenzustandsinventur - Konzeption, Durchführung und Bewertung. Institut für Bodenforschung, Universität für Bodenkultur. Wien.

Breen, K. \& E. Lévesque 2008. The influence of biological soil crusts on soil characteristics along a High Arctic glacier foreland, Nunavut, Canada. Arctic, Antarctic, and Alpine Research 40: 287-297.

Brotherson, J.D. \& S.R. Rushford 1983. Influence of cryptogamic crusts on moisture relationships of a soil 
in Navajo National Monument, Arizona. Great Basin Naturalist 43: 73-79.

Brotherson, J.D., S.R. Rushford \& J.R. Johansen 1983. Effects of long-term grazing on cryptogam crust cover in Navajo National Monument, Arizona. Journal of Range Management 36: 579-581.

Büdel, B. 2002. Diversity and ecology of biological crusts. Progress in Botany 63: 386-404.

Büdel, B. 2003. Synopsis: Comparative biogeography of soil crust biota and communities. In: Belnap, J. \& O.L. Lange (eds.), Biological soil crusts: structure, function, and management. Ecological Studies 150: 141-152.

Büdel, B. (2005): Microorganisms of biological crusts on soil surfaces. In: Buscot, F. \& A. Varma (eds.), Microorganisms in soils: roles in genesis and functions. Soil Biology 3: 307-325.

Campell, S.E., J.S. Seeler \& S. Golubic 1989. Desert crust formation and soil stabilization. Arid Land Research and Management 3: 217-228.

Danin, A., Y. Bar-Or, I. Dor \& T. Yisraeli 1989. The role of cyanobacteria in stabilization of sand dunes in southern Israel. Ecologia Mediterranea 15: 55-64.

Davey, A. \& H.J. Marchant 1983. Seasonal variation in nitrogen fixation by Nostoc commune Vaucher at the Vestfold Hills, Antarctica. Phycologia 22: 377-385.

Dickson L.G. 2000. Constraints to nitrogen fixation by cryptogamic crusts in a polar desert ecosystem, Devon Island, N.W.T., Canada. Arctic, Antarctic, and Alpine Research 32: 40-45.

Eldridge, D.J. 1998. Trampling of microphytic crusts on calcareous soils and its impact on erosion under rain-impacted flow. Catena 33: 221-239.

Eldridge, D.J. 2003. Biological soil crusts and water relations in Australian deserts. In: Belnap, J. \& O.L. Lange (eds.), Biological soil crusts: structure, function, and management. Ecological Studies 150: 119-132.

Eldridge, D.J. \& R.S.B. Greene 1994. Microbiotic soil crusts - a review of their roles in soil and ecological processes in the rangeland of Australia. Australian Journal of Soil Research 32: 389-415.

Eldridge, D.J. \& J.F. Leys 2003. Exploring some relationships between biological soil crusts, soil aggregation and wind erosion. Journal of Arid Environments 53: 457-466.

Ettl, H. \& G. Gärtner 1995. Syllabus der Boden-, Luftund Flechtenalgen. Stuttgart.

Evans, R.D. \& J. Belnap 1999. Long-term consequences of disturbance on nitrogen cycling in an arid ecosystem. Ecology 80: 150-160.

Fischer, M.A., W. Adler \& K. Oswald 2008. Exkursionsflora für Österreich, Liecbtenstein und Südtirol. Land Oberösterreich. 3. Aufl., Biologiezentrum der OÖ Landesmuseen. Linz.

Frey, W., J.P. Frahm, E. Fischer \& W. Lobin 1995. Die Moos- und Farnpflanzen Europas.

Gärtner, G. 1996. ASIB - The culture collection of algae at the Botanical Institute of the University at Innsbruck (Austria), catalogue of strains 1996. Berichte des Naturwissenschaftlich-Medizinischen Vereins in Innsbruck 83: 45-69.

Gold, W.G., K.A. Glew. \&. L.G. Dickson 2001. Functional influences of cryptobiotic surface crusts in an alpine tundra basin of the Olympic Mountains, Washington, USA. Northwest Science 73: 315-326.

Graber, W.K., R.T.W. Siegwolf, W. Nater, \& S. Leonardi 1996. Mapping the impact of anthropogenetic deposition on high elevation alpine forests. Environmental Software 11: 59-64.

Griffiths, E. 1965. Microorganisms and soil structure. Biological Reviews 40: 129-142.

Grims, F. 1999. Die Laubmoose Österreichs. Catalogus flora Austriae. II Teil, Bryophyten (Moose) Heft 1, Musci (Laubmoose). Biosystematics and Ecology Series 15.

Gruber, F. 1980. Die Verstaubung der Hochgebirgsböden im Glocknergebiet. Veröffentlichungen des Österreichischen MAB-Hochgebirgsprogramms Hohe Tauern 3: 69-91.

Hafellner, J. \& R. Türk 2001. Die lichenisierten Pilze Österreichs - eine Checkliste der bisher nachgewiesenen Arten mit Verbreitungsangaben. Stapfia 76: $1-167$.

Harper, K.T. \& J. Belnap 2001. The influence of biological soil crusts on mineral uptake by associated vascular plants. Journal of Arid Environments 47: 347-357.

Haselwandter, K., A. Hofmann, H.P. Holzmann \& D. J. Read 1983. Availability of nitrogen and phosphorous in the nival zone of the Alps. Oecologia 57: 266-269.

Horne, A.J. 1972. The ecology of nitrogen fixation on Signy Island, South Orkney Islands. British Antarctic Survey Bulletin 27: 1-18.

Housman, D.C., H.H. Powers, A.D. Collins \& J. Belnap 2006. Carbon and nitrogen fixation differ between successional stages of biological soil crusts in the Colorado Plateau and Chihuahuan Desert. Journal of Arid Environments 66: 620-634.

Huber, E., W. Wanek, M. Gottfried, H. Pauli, P. Schweiger, S.K. Arndt, K. Reiter \& A. Richter 2007. Shift in soil-plant nitrogen dynamics of an alpine-nival ecoton. Plant Soil 301: 65-76.

Huber, K., T. Peer, A. Tschaikner, R. Türk \& J.P. Gruber 2007. Characteristics and function of soil crusts in different successional stages in alpine environments, outlined on an alpine lime scree in the Großglockner region (Austria). Mitteilungen der Österreichischen Bodenkundlichen Gesellschaft 74: 111-126.

Küfmann, C. 2009. Flugstaubeintrag und Bodenbildung im Karst der Nördlichen Kalkalpen. Nationalpark Berchtesgaden, Forschungsbericht 54: 1-159.

Johansen, J.R. 1993. Cryptogamic crusts of semiarid and arid lands of North America. Journal of Phycology 29: 140-147.

Lange, O.L. 2003. Wenn kleine Organismen große Wirkung zeigen. Biowissenschaften, Forschung 4: 14-18.

Lange O.L., A. Meyer, H. Zellner \& U. Heber 1994. Photosynthesis and water relations of lichen soil crusts: field measurements in the coastal fog zone of the Namib desert. Functional Ecology 8: 253-264. 
Lange, O.L., J. Belnap \& H. Reichenberger 1998. Photsynthesis of the cyanobacterial soil-crust lichen Collema tenax from arid lands in southern Utah, USA: role of water content on light and temperature response of $\mathrm{CO}_{2}$ exchange. Functional Ecology 12: 195-202.

Lazaro, L., Y. Canton, A. Sole-Benet, J. Bevan, R. Alexander, L.G. Sancho \& J. Puigdefabregas 2008. The influence of competition between lichen colonization and erosion in the evolution of soil surfaces in the Tabernas badlands (SE Spain) and its landscape effects. Geomorphology 102: 252-266.

Lösch, R., L. Kappen \& A. Wolf 1983. Productivity and temperature biology of two snow bed bryophytes. Polar Biology 1: 243-248.

McCalla, M.T. 1944. Water drop method of determining stability of soil structure. Soil Science 58: 117-121.

Moore, P.D. 1998. Desert ecology: Life in the upper crust. Nature 393: 419-420.

Perez, F.L. 1997. Microbiotic crusts in the high equatorial Andes, and their influence on paramo soils. Catena 31: 173-198.

Poelt, J. 1969. Bestimmungsschlüssel europäischer Flechten.

Poelt J. \& A. Vězda 1977. Bestimmungsschlüssel europä̈scher Flechten. Ergänzungsheft I.: 1-258.Vaduz.

Poelt J. \& A. Vězda 1981. Bestimmungsschlüssel europäischer Flechten. Ergänzungsheft II: 1-390. Vaduz.

Posch, A. 1977. Bodenkundliche Untersuchungen im Bereich der Glocknerstraße in den Hohen Tauern. Veröff. Veröffentlichungen des Österreichischen MAB-Hochgebirgsprogramms Hohe Tauern 1: 111-121. Innsbruck.

Psenner, R. \& U. Nickus 1986. Snow chemistry of a glacier in the Central Eastern Alps (Hintereiserferner, Tyrol, Austra). Zeitschrift für Glescherkunde und Glaczialgeologie 22: 1-18.

Riedl, H. 1977. Micro-biocoenosis of Anthelia juratzkana. The Bryologist 80: 332-334.

Russow, R., M. Veste \& F. Böhme 2005. ${ }^{15} \mathrm{~N}$ approach to determine the biological fixation of atmospheric nitrogen by biological soil crusts of the Negev desert. Rapid Communications Mass Spectrometry 19: 3451-3456.

Shields, L.M. \& W. Durrell 1964. Algae in relation to soil fertility. The Botanical Review 30, 1: 92-128.

Smith, G.D., R.M. Lynch, G. Jacobson \& C.J. Barnes 1990. Cyanobacterial nitrogen fixation in arid soils of central Australia. FEMS Microbiology Letters 74: 79-90.

Tirkey, J. \& P. Adhikary 2005. Cyanobacteria in biological soil crusts of India. Current Science 89: 515-521.

Tschaikner, A., G. Gärtner \& W. Kofler 2008. Coelastrella aeroterrestrica (Chlorophyta, Scenodesmoideae) - a new, obviously often overlooked aeroterrestrial species. Algological Studies 128: 11-20.

Türk, R. \& G. Gärtner 2003. Biological soil crusts of the subalpine, alpine, and nival areas in the Alps. In: Belnap. G. \& O.L. Lange (eds.), Biological soil crusts: structure, function, and management. Ecological Studies 150: 67-73.
West, N.E. 1990. Structure and function of soil microphytic crusts in wildland ecosystems of arid and semiarid regions. Advances in Ecological Research 20: 179-223.

Wirth, V. 1995. Die Flechten Baden-Württembergs, Teil 1 und 2. Stuttgart.

Wischmeier, H. \& D.D. Smith 1978. Predicting rainfall erosion losses: aguide to conservationplanning. Washington DC.

WRB 2006. World reference base for soil resources. 2006 edition. FAO. Rome.

\section{Authors}

Thomas Peer ${ }^{1}$

Associate Professor at the Department of Biology of Organisms, expert on vegetation science and soil ecology.

thomas.peer@sbg.ac.at

\section{Roman Türk'}

Professor at the Department of Biology of Organisms, expert on lichen taxonomy and physiology. roman.tuerk@sbg.ac.at

Johann Peter Gruber ${ }^{1}$

Wrote his PhD thesis on Juncus articus in the Alps. Currently working as curator at the Botanical Gardens ofthe University of Salzburg. Lecturer at the University of Salzburg and expert on bryophytes. johann.gruber@sbg.ac.at

${ }^{1}$ University of Salzburg, Department of Organism Biology, Hellbrunnerstrasse 34, 5020 Salzburg, Austria

\section{Angelika Tschaikner}

Wrote her $\mathrm{PhD}$ thesis on "Soil algae in the alpine regions of Tyrol (Ötztal, Austria)" at the University of Innsbruck. Currently working as quality manager at the company Spar Österreich.

University of Innsbruck, Institute of Botany, Sternwartestrasse 15, 6020, Innsbruck, Austria angelika.tschaikner@gmx.at 